\title{
THE RELATIONSHIP BETWEEN PLANTING DATES AND SOME CLIMATIC FACTORS ON THE INFESTATION OF EGGPLANT CULTIVARS WITH THE TWO-SPOTTED SPIDER MITE, Tetranychus urticae KOCH.
}

Abou El-Saad, A.K.

Plant Protection Research Institute, Agric. Res. Center, Dokki, Giza, Egypt.

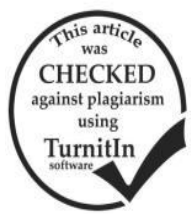

\section{ABSTRACT}

Field studies were carried out at the Experimental Farm, Faculty of Agriculture, Assiut University, during two successive seasons of 2014 and 2015 used three planting dates (early summer, summer and nili plantations) in order to study the relationship between planting dates as well as some of the climatic factors (temperatures and relative humidity) on the census of the twospotted spider mite, Tetranychus urticae Koch on some eggplant cultivars (i.e., black balady, white balady and romy).

The results obtained showed that the three tested planting dates gave significant and highly significant differences between mean numbers of $T$. urticae Koch recorded on the eggplant cultivars. The highest general mean number of $T$. urticae was recorded on the nili plantation followed by summer and early summer ones during the two growing seasons of 2014 and 2015. On the other side, the Max. and Min. temperatures gave highly significant and significant correlation values on the census of $T$. urticae through the three tested planting dates. While, the relative humidity showed negative insignificant correlations with the $T$. urticae census in the early summer plantation and positive significant in summer and nili ones on the three tested eggplant cultivars during 2014 and 2015 growing seasons.

It can be concluded that, the planting dates and climatic factors have a strong effect on the rate of eggplant cultivars infestation with $T$. urticae. Therefore, severe injury of the pest can be avoided by using the early summer plantation date. Keywords: eggplant - planting dates - climatic factors - Tetranychus urticae Koch.

\section{INTRODUCTION}

Among 1250 species of spider mites known in the world, the two-spotted spider mite (TSSM), Tetranychus urticae Koch (Acari: Tetranychidae) is the most important phytophagous species. It attacks more than 300 host plants including vegetables (e.g. beans, eggplant, pepper, tomato, potato etc.); fruits (e.g. strawberry, raspberry, current, pear etc.) and ornamental plants, as shown in (Le Goff et al., 2009).

This scourge is causing yellowing and death of the infested plant leaves. This results in the lack of leaf surface less the energy used in maturing fruit. Entire plants in heavy infested areas of the field may be defoliated. These mites also produce webbing on plants where they feed. Damage frequently occurs in high temperature and hot spots such as areas of the field near dusty roads (Abdel-Aziz et al., 2002; Ibrahim, 2009; Aziza et al., 2012 and Gadi and Miller, 2014).

Solanaceous vegetable plants are very important in all agricultural regime, which used as important food in many countries of the world. Eggplant (Solanum melongena L.) is considered one of the most important solanaceous vegetable crop in Egypt (Abdel-Megied, 1998; Al-Said and Kamal, 2005; Solieman et al., 2012 and Sadek et al., 2013).

On the other hand, the influence of planting dates and climatic factors on the census of the two-spotted spider mite on eggplant could be used as an items in integrated pest management programs (El-Khateeb et al., 2001; Habashy and Saweeres, 2005; Baradaran et al., 2007 and Mubammad et al., 2010).

Thus, the aim of the present work is to study the relationship of planting dates and climatic factors on eggplant cultivars infestation with $T$. urticae Koch during two successive seasons of 2014 and 2015, to severe as an introduction to the use of integrated pest management.

\section{MATERIALS AND METHODS}

The work herein was carried out in the Experimental Farm of the Faculty of Agriculture, Assiut University, during two successive growing seasons of 2014 and 2015 in a loam clay soil. An area of about 3/8 feddan was cultivated with three eggplant cultivars (e.g., black balady, white balady and romy). The experiments conducted in complete randomized block design with three replicates $3 \times 3.5$ (1/400 feddan). Seeds of each cultivar were sown in three planting dates (the first in March $1^{\text {st }}$ for early summer, the second in May $1^{\text {st }}$ for summer and the third in July $1^{\text {st }}$ for nili plantation) during 2014 and 2015 growing seasons.

Normal agricultural practices were applied a part from the use of any pesticides transactions. Sampling started after three weeks from planting date and prolonged to the harvest time, each sample comprised 5 leaflets picked at random representing the plant levels from each replicate.

Samples were put in plastic bags and transferred to the laboratory in the same day for examination and counting the mobile stages of $T$. urticae by the aid of stereoscopic microscope.

The meteorological data (maximum \& minimum temperature and relative humidity) were recorded during each inspection date. Records were obtained from the meteorological station located at Assiut University.

The obtained data were statistically analyzed according to Snedecor and Cochran (1971) and the means were compared by using Least Significant Difference (L.S.D.) at level of $5 \%$.

The relationships between the population density of $T$. urticae and planting dates \& certain prevailing climatic factors (maximum \& minimum temperature and relative humidity) were statistically analyzed by 
using simple correlation according to Gomez and Gomez (1984).

\section{RESULTS AND DISCUSSION}

\section{I- Planting dates:}

Data presented in Tables $(1 \& 2)$ show the relationship of planting dates on the infestation of eggplant cultivars; (black balady, white balady and romy) with $T$. urticae during 2014 and 2015 growing seasons.

1- The first planting date (early summer plantation):

Data of the 2014 season (Table 1) show that the mean numbers of $T$. urticae began to appear on the eggplant cultivars; (black balady, white balady and romy) in the fourth week of March in low numbers
(2.33, 3.33 and 1.00 individuals/15 leaflets), then the numbers increased gradually to reach its maximum in the fourth week of May with almost high numbers (38.33, 50.33 and 25.67 ind./15 leaflets) for the three cultivars mentioned above, respectively.

During 2015 season (Table 2), the numbers of $T$. urticae individuals were high as compared with that in 2014 season. The first appearance of mite was occurred in the fourth week of March on the three eggplant cultivars with scarce numbers $(3.33,5.00$ and 1.67 ind./15 leaflets), then the numbers increased gradually to reach its maximum in the fourth week of May with almost high numbers $(52.33,59.67$ and 26.67 ind./15 leaflets) for the three cultivars, respectively.

Table (1). Relationship between planting dates and the infestation of eggplant cultivars with $T$. urticae during 2014 growing season.

\begin{tabular}{|c|c|c|c|c|c|c|c|c|c|c|c|}
\hline $\begin{array}{l}\text { Cultivar } 1^{\text {st }} \\
\text { planting } \\
\text { date }\end{array}$ & $\begin{array}{c}\text { Black } \\
\text { balady }\end{array}$ & $\begin{array}{l}\text { White } \\
\text { balady }\end{array}$ & Romy & $\begin{array}{c}\text { Cultivar } \\
2^{\text {nd }} \\
\text { planting } \\
\text { date }\end{array}$ & $\begin{array}{c}\text { Black } \\
\text { balady }\end{array}$ & $\begin{array}{l}\text { White } \\
\text { balady }\end{array}$ & Romy & $\begin{array}{c}\text { Cultivar } \\
\mathbf{3}^{\text {rd }} \\
\text { planting } \\
\text { date }\end{array}$ & $\begin{array}{c}\text { Black } \\
\text { balady }\end{array}$ & $\begin{array}{l}\text { White } \\
\text { balady }\end{array}$ & Romy \\
\hline $22 / 3 / 2014$ & 2.33 & 3.33 & 1.00 & $22 / 5 / 2014$ & 35.67 & 42.00 & 25.00 & $22 / 7 / 2014$ & 51.67 & 65.67 & 31.33 \\
\hline 29 & 2.67 & 4.67 & 1.00 & 29 & 38.00 & 47.33 & 29.33 & 29 & 61.33 & 70.33 & 38.67 \\
\hline Mean & 2.50 & 4.00 & 1.00 & Mean & 36.83 & 44.66 & 27.16 & Mean & 56.50 & 68.00 & 35.00 \\
\hline $5 / 4$ & 3.67 & 7.00 & 1.67 & $5 / 6$ & 48.33 & 59.00 & 36.33 & $5 / 8$ & 67.67 & 78.00 & 41.67 \\
\hline 12 & 5.33 & 8.67 & 2.67 & 12 & 50.33 & 64.67 & 37.33 & 12 & 69.67 & 82.00 & 47.67 \\
\hline 19 & 7.00 & 11.33 & 3.00 & 19 & 55.67 & 68.33 & 41.00 & 19 & 73.67 & 89.00 & 52.00 \\
\hline 26 & 8.67 & 15.00 & 5.67 & 26 & 59.33 & 72.33 & 44.00 & 26 & 81.00 & 95.00 & 55.33 \\
\hline Mean & 6.17 & 10.50 & 3.25 & Mean & 53.41 & 66.08 & 39.66 & Mean & 73.00 & 86.00 & 49.17 \\
\hline $3 / 5$ & 13.00 & 15.67 & 10.00 & $3 / 7$ & 67.00 & 82.00 & 48.00 & $2 / 9$ & 84.00 & 97.00 & 59.00 \\
\hline 10 & 20.33 & 26.00 & 15.33 & 10 & 74.67 & 90.33 & 53.33 & 9 & 69.67 & 86.00 & 45.00 \\
\hline 17 & 30.33 & 43.67 & 23.67 & 17 & 79.33 & 97.00 & 56.00 & 16 & 62.00 & 81.33 & 38.67 \\
\hline 24 & 38.33 & 50.33 & 25.67 & 24 & 61.00 & 68.00 & 44.33 & 23 & 59.00 & 75.33 & 33.67 \\
\hline 31 & 26.67 & 39.67 & 17.00 & 31 & 47.00 & 57.67 & 38.00 & 30 & 50.00 & 74.00 & 29.67 \\
\hline Mean & 25.73 & 35.07 & 18.33 & Mean & 65.80 & 79.00 & 47.93 & Mean & 64.93 & 82.73 & 41.20 \\
\hline $7 / 6$ & 20.67 & 31.33 & 15.67 & $7 / 8$ & 40.67 & 49.67 & 31.00 & $7 / 10$ & 41.33 & 68.00 & 24.67 \\
\hline 14 & 16.67 & 22.33 & 13.00 & 14 & 38.00 & 45.67 & 23.33 & 14 & 37.67 & 61.00 & 20.67 \\
\hline Mean & 18.67 & 26.83 & 14.33 & Mean & 39.33 & 47.67 & 27.16 & Mean & 39.50 & 64.50 & 22.67 \\
\hline G. mean & $15.05 \mathrm{C}^{\prime}$ & $21.46 \mathrm{C}$ & $10.41 \mathrm{~B}^{\prime \prime}$ & G. mean & $53.46 \mathrm{~B}^{\prime}$ & $64.92 \mathrm{~B}$ & $39.00 \mathrm{~A}^{\prime \prime}$ & G. mean & $62.21 \mathrm{~A}^{\prime}$ & $78.67 \mathrm{~A}$ & $39.85 \mathrm{~A}^{\prime \prime}$ \\
\hline
\end{tabular}

Generally, the average mean numbers of $T$. urticae were variable according to months, on the three eggplant cultivars the numerical density of $T$. urticae of season 2014 was significantly low during March and April and increased significantly to attain its maximum peak during May (25.73, 35.07 and 18.33 ind.) and (39.13, 48.40 and 21.53 ind.) for 2015 season, respectively.

\section{2- The second planting date (summer plantation):}

During 2014 season (Table 1), data revealed that the first appearance of mite individuals was recorded in the fourth week of May with an average numbers of $35.67,42.00$ and 25.00 individuals/15 leaflets, then the numbers increased gradually to reach its maximum in third week of July with an average of 79.33, 97.00 and 56.00 ind./15 leaflets, on eggplant cultivars, respectively.

At 2015 season, data in Table (2) showed that the mean numbers of $T$. urticae started to appear on eggplant cultivars in the fourth week of May with an average of 39.00, 48.67 and 26.67 ind./15 leaflets), then the numbers increased gradually to reach its maximum in third week of July with an average of $82.33,123.33$ and 69.67 ind./15 leaflets, for the three cultivars, respectively.

Generally, the average numbers of mite were variable on eggplant cultivars according to months, the highest density of mite was recorded in July with an average of $65.80,79.00$ and 47.93 ind. during 2014 season and 72.40, 105.00 and 58.27 ind. during 2015 growing season, for the three eggplant cultivars, respectively.

\section{3- The third planting date (nili plantation):}

In 2014 growing season, data (Table 1) data showed that the numbers of T. urticae started to appear on eggplant cultivars in the fourth week of July with mean numbers an average of 51.67, 65.67 and 31.33 individuals/15 leaflets, then the numbers increased gradually to reach their maximum in first week of September with mean numbers of $84.00,97.00$ and 59.00 ind./15 leaflets, for the three cultivars, respectively. 
During the second season (Table 2), the numbers of $T$. urticae individuals were the highest as compared with that in the first season. The first appearance of mite was recorded in the fourth week of July with an average mean numbers of 57.33, 77.67 and 36.67 ind./15 leaflets, then the numbers increased gradually to reach their maximum in first week of September with an average numbers of $110.00,118.67$ and 77.33 ind./15 leaflets, for the three eggplant cultivars, respectively.

Table (2). Relationship between planting dates and the infestation of eggplant cultivars with $T$. urticae during 2015 growing season.

\begin{tabular}{|c|c|c|c|c|c|c|c|c|c|c|c|}
\hline $\begin{array}{l}\text { Cultivar } 1^{\text {st }} \\
\text { planting } \\
\text { date }\end{array}$ & $\begin{array}{c}\text { Black } \\
\text { balady }\end{array}$ & $\begin{array}{l}\text { White } \\
\text { balady }\end{array}$ & Romy & $\begin{array}{l}\text { Cultivar } \\
2^{\text {nd }} \\
\text { planting } \\
\text { date }\end{array}$ & $\begin{array}{c}\text { Black } \\
\text { balady }\end{array}$ & $\begin{array}{l}\text { White } \\
\text { balady }\end{array}$ & Romy & $\begin{array}{c}\text { Cultivar } \\
3^{\text {rd }} \\
\text { planting } \\
\text { date }\end{array}$ & $\begin{array}{l}\text { Black } \\
\text { balady }\end{array}$ & $\begin{array}{l}\text { White } \\
\text { balady }\end{array}$ & Romy \\
\hline $22 / 3 / 2015$ & 3.33 & 5.00 & 1.67 & $22 / 5 / 2015$ & 39.00 & 48.67 & 26.67 & $22 / 7 / 2015$ & 57.33 & 77.67 & 36.67 \\
\hline 29 & 6.00 & 9.33 & 2.67 & 29 & 41.33 & 54.33 & 33.33 & 29 & 69.67 & 85.67 & 43.33 \\
\hline Mean & 4.66 & 7.16 & 2.17 & Mean & 40.16 & 51.50 & 30.00 & Mean & 63.50 & 81.67 & 40.00 \\
\hline $5 / 4$ & 9.00 & 12.67 & 4.33 & $5 / 6$ & 52.33 & 68.00 & 39.00 & $5 / 8$ & 80.00 & 90.33 & 49.00 \\
\hline 12 & 12.33 & 18.33 & 7.00 & 12 & 57.33 & 73.33 & 25.00 & 12 & 87.33 & 93.67 & 54.00 \\
\hline 19 & 19.00 & 23.67 & 9.67 & 19 & 62.67 & 84.67 & 48.67 & 19 & 91.00 & 97.00 & 62.33 \\
\hline 26 & 24.33 & 30.33 & 14.67 & 26 & 70.33 & 96.33 & 52.00 & 26 & 99.33 & 107.67 & 70.33 \\
\hline Mean & 16.16 & 21.25 & 8.92 & Mean & 60.66 & 80.58 & 41.17 & Mean & 89.41 & 97.17 & 58.91 \\
\hline $3 / 5$ & 27.33 & 38.67 & 17.33 & $3 / 7$ & 74.00 & 104.00 & 58.67 & $2 / 9$ & 110.00 & 118.67 & 77.33 \\
\hline 10 & 33.00 & 44.33 & 19.67 & 10 & 79.00 & 119.00 & 66.00 & 9 & 88.67 & 106.33 & 60.67 \\
\hline 17 & 44.00 & 53.33 & 23.67 & 17 & 82.33 & 123.33 & 69.67 & 16 & 76.33 & 92.00 & 47.67 \\
\hline 24 & 52.33 & 59.67 & 26.67 & 24 & 65.67 & 99.67 & 53.00 & 23 & 69.00 & 84.00 & 36.33 \\
\hline 31 & 39.00 & 46.00 & 20.33 & 31 & 61.00 & 79.00 & 44.00 & 30 & 58.33 & 80.00 & 33.33 \\
\hline Mean & 39.13 & 48.40 & 21.53 & Mean & 72.40 & 105.00 & 58.27 & Mean & 80.47 & 96.20 & 51.07 \\
\hline $7 / 6$ & 33.67 & 39.00 & 17.33 & $7 / 8$ & 48.00 & 63.00 & 35.33 & $7 / 10$ & 43.17 & 74.33 & 29.67 \\
\hline 14 & 29.67 & 32.33 & 14.00 & 14 & 42.33 & 56.33 & 29.00 & 14 & 34.00 & 69.00 & 25.33 \\
\hline Mean & 31.67 & 35.66 & 15.66 & Mean & 45.16 & 59.66 & 32.16 & Mean & 38.83 & 71.66 & 27.50 \\
\hline G. mean & $25.61 \mathrm{C}^{\prime}$ & $31.74 \mathrm{C}$ & $13.77 \mathrm{C}^{\prime \prime}$ & G. mean & $59.64 \mathrm{~B}^{\prime}$ & $82.28 \mathrm{~B}$ & 44.64 B" & G. mean & $74.20 \mathrm{~A}^{\prime}$ & $90.49 \mathrm{~A}$ & $48.15 \mathrm{~A}^{\prime \prime}$ \\
\hline
\end{tabular}

Generally, the average numbers of the twospotted spider mite were variable according to months on the three eggplant cultivars; the number of mite were the highest during August of the first year $(73.00,86.00$ and 49.17 ind.) and (89.41, 97.17 and 58.91 ind.) in the second year, respectively.

Also, data in Tables ( $1 \& 2)$ showed significant and highly significant differences recorded between general mean numbers of $T$. urticae on the three eggplant cultivars, whereas the highest general mean numbers of mite (62.21, 78.67 and 39.85 ind.) recorded on the nili plantation followed by summer plantation (53.46, 64.92 and 39.00 ind.) and early summer one (15.05, 21.46 and 10.41 ind.) during the first season, and (74.20, 90.49 and 48.15 ind.) followed by summer plantation (59.64, 82.28 and 44.64 ind.) and early summer plantation (25.61, 31.74 and 13.77 ind.) during 2015 season, respectively.

The variation between mean numbers of mite on the three eggplant cultivars and planting dates (through March, May and July) may be due mainly to the leaf characteristics and some biotic and climatic factors.

Similar results were obtained by many authors such as; Abou-Attia et al. (2004) who found that the peak number of the two-spotted spider mite were recorded on cucumber and tomato through April and May. While, El-Khayat et al. (2010) when tested three planting dates (April $1^{\text {st }}, 15^{\text {th }}$ and $30^{\text {th }}$ ) of cowpea on the levels of infestation with two mite species (T. urticae \& T. cucurbitacearum) whereas data found that the mean numbers of different stages of mites were increased by delaying the planting date and Awadalla et al. (2011) showed that the two spotted spider mite, T. urticae reached the highest number on kidney bean plants in late summer plantation during the two seasons of 2009 $\&$ 2010. Mohamed (2011) studied the effect of four planting dates of squash seeds (March $15^{\text {th }}$, April $1^{\text {st }}$, $15^{\text {th }}$ and May $1^{\text {st }}$ ) on levels of infestation with three piercing sucking pests, the results showed that the degree of infestation by previous pests increased significantly by delaying planting date.

\section{II- Climatic factors:}

Data in Table (3) recorded the correlation coefficient between main climatic factors (max., min. temperature and relative humidity) and the census of the pest on the three eggplant cultivars (black balady, white balady and romy) through the three planting dates (March $1^{\text {st }}$, May $1^{\text {st }}$ and July $1^{\text {st }}$ ) during the two seasons of 2014 \& 2015.

The results in the first season showed highly significant correlations $(\mathrm{r}=0.739,0.721 ; 0.792,0.761$ and $0.682,0.602)$ and $0.845,0.810 ; 0.869,0.851$ and $0.703,0.688$ between temperature (max. \& min.) and the population density of mite on the three eggplant cultivars during the first \& the second planting dates, respectively, while significant correlations $(r=0.331$, $0.301 ; 0.349,0.313$ and $0.229,0.181$ ) were recorded between temperature (max. \& min.) and the census of mite on black balady, white balady and romy, cultivars during the third planting date, respectively.

On the other hand, negative insignificant correlations $(r=-0.233,-0.196$ and -0.236$)$ were counted between relative humidity and the numbers of mite on black balady, white balady and romy cultivars, during 
the first planting date, respectively. While, positive significant correlations $(r=0.234,0.341$ and 0.196 and $0.291,0.352$ and 0.241 ) were counted between relative humidity and the numbers of mite on black balady, white balady and romy during second and third planting dates, respectively.

During 2015 season, data in Table (3) showed highly significant correlations $(\mathrm{r}=0.752,0.734 ; 0.801$, $0.783 ; 0.707,0.674$ and $0.861,0.819 ; 0.883,0.864$ and
$0.723,0.701)$ recorded between temperature (max. \& min.) and the population density of mite on the three eggplant cultivars during the first and the second planting dates, respectively. While, significant correlations $(\mathrm{r}=0.349,0.321 ; 0.372,0.343$ and 0.281 , 0.217) were accounted between max. \& min. temperature and the mite population on black balady, white balady and romy cultivars during the third planting date, respectively.

Table (3). The relationship between main climatic factors (temperature and relative humidity) and the population density of $T$. urticae on the eggplant cultivars through three planting dates during 2014 and 2015 seasons.

\begin{tabular}{|c|c|c|c|c|c|c|}
\hline \multirow{2}{*}{$\begin{array}{l}\text { Planting date \& } \\
\text { cultivars }\end{array}$} & \multicolumn{3}{|c|}{2014} & \multicolumn{3}{|c|}{2015} \\
\hline & Max. temp. & Min. temp. & R.H. & Max. temp. & Min. temp. & R.H. \\
\hline \multicolumn{7}{|l|}{ First planting date: } \\
\hline Black balady & $0.739 * *$ & $0.721 * *$ & -0.223 & $0.752 * *$ & $0.734 * *$ & -0.193 \\
\hline White balady & $0.792 * *$ & $0.761 * *$ & -0.196 & $0.801 * *$ & $0.783 * *$ & -0.171 \\
\hline Romy & $0.682 * *$ & $0.602 * *$ & -0.236 & $0.707 * *$ & $0.674 * *$ & -0.214 \\
\hline \multicolumn{7}{|c|}{ Second planting date: } \\
\hline Black balady & $0.845^{* *}$ & $0.810 * *$ & $0.234^{*}$ & $0.861 * *$ & $0.819 * *$ & $0.251 *$ \\
\hline White balady & $0.869 * *$ & $0.851 * *$ & $0.341 *$ & $0.883 * *$ & $0.864 * *$ & $0.373 *$ \\
\hline Romy & $0.703 * *$ & $0.688 * *$ & $0.196 *$ & $0.723 * *$ & $0.701 * *$ & $0.213 *$ \\
\hline \multicolumn{7}{|l|}{ Third planting date: } \\
\hline Black balady & $0.331 *$ & $0.301 *$ & $0.291 *$ & $0.349 *$ & $0.321 *$ & $0.305 *$ \\
\hline White balady & $0.349 *$ & $0.313 *$ & $0.352 *$ & $0.372 *$ & $0.343^{*}$ & $0.366^{*}$ \\
\hline Romy & $0.229 *$ & $0.181 *$ & $0.241 *$ & $0.281 *$ & $0.217 *$ & $0.269 *$ \\
\hline
\end{tabular}

* Significant at 0.05 probability level. $\quad$ ** Significant at 0.01 probability level.

Also, the relative humidity during the first planting date showed negative insignificant correlations $(\mathrm{r}=-0.193$, -0.171 and -0.214 ) with the mite population on the three cultivars and positive significant correlations $(r=0.251$, 0.373 and 0.213 and $0.305,0.366$ and 0.269 ) were recorded between relative humidity and the mite populations on black balady, white balady and romy during second and third planting dates, respectively.

The results of the correlation coefficient between some environmental conditions and the population density of the two-spotted spider mite were studied by many authors, Taha et al. (2001) recorded significant correlations among infestation levels of soybean with mite population and the climatic factors (temperature and relative humidity); El-Doksh (2006) recorded positive and significant correlations between mite population and max., min. temperature and relative humidity on Giza 111 soybean variety in 2003 season, respectively. While, the author recorded negative and highly significant correlations occurred between mite populations and max. temperature and relative humidity in 2004, on Giza 21 soybean variety, respectively and Bedawy et al. (2011) showed significant and insignificant positive and/or negative correlations recorded between (temperature and relative humidity) and the population density of the spider mite on eggplant.

\section{REFERENCES}

Abdel-Aziz, S.Y.; S.A. Mohamed and I.S. AbdelWahab (2002). Efficiency of four seed plant oils for controlling certain pests in eggplant fields. $2^{\text {nd }}$ Inter. Conf., P.P.R.I. Cairo, Egypt, 21-24 Dec.
Abdel-Megied, M.H.H. (1998). Studies of induced variability for improving some eggplant cultivars. Ph.D. Thesis, Fac. of Agric., Assiut Univ., 105 pp.

Abou-Attia, F.A.; F.A. Sharshir; M.S. Tadros and Gh.M.A. El-Shafei (2004). Relative abundance and spatial distribution of Liriomyza trifolii (Burgees), Thrips tabaci (Lind.) and Tetranychus urticae Koch populations attacking cucumber and tomato grown under greenhouses at Kafr ElSheikh. J. Agric. Res., Tanta Univ., 30 (2): 342357.

Al-Said, A.M. and A.M. Kamal (2005). Enhancement of growth and yield of eggplant (Solanum melongena L.) by foliar nutrition of potassium citrate and iron-shelate in early summer season. J. Agric. Sci., Mansoura Univ., 30 (12): 7863-7869.

Awadalla, S.S.; L.M. Shanab; M.E. El-Naggar and S.M. Abo-Zeid (2011). Influence of different varieties and planting dates on the main pests infesting kidney beans. J. Plant Prot. and Pathology, Mansoura Univ., 2 (4): 519-531.

Aziza, M.M.; A.M.M. Abou-Zaid; E.M. Bakr; S.A. Yassin and N.A.A. Hameed (2012). Abundance of three sap sucking pests on three eggplant cultivars with utilization of Phytoseiulus persimilis A.H. against Tetranychus urticae Koch control. Acarines, 6: 49-53.

Baradaran, A.P.; A. Masoud and R.A. Shafiei (2007). Study on different eggplant cultivars for infestation to the two-spotted spider mite (Tetranychus urticae Complex) in Varamin Region. Seed and Plant Volume 23 (1): 15-29. 
Bedawy, A.M.; K.H. Abdel-Gawad; N.A. Ali and S.A. Eraky (2011). Survey and seasonal fluctuations of some arthropod species infesting eggplants in Assiut. Assiut J. of Agric. Sci., 42 (The $5^{\text {th }}$ Conf. of Young Sci., Fac. of Agric., Assiut Univ.) (461467).

El-Doksh, R.A. (2006). Susceptibility of four soybean varieties to infestation with some sucking pests and cotton leafworm and the effect of main weather factors on infestation. J. Agric. Sci., Mansoura Univ., 31 (4): 2369-2385.

El-Khateeb, H.M.; A.E. Abdel-Aziz and A.K.F. Iskandar (2001). Effect of planting date of some Solanaceous vegetable crops on the two-spotted spider mite, Tetranychus urticae Koch population. Fayoum J. Agric. Res. \& Dev., 15 (2): 7-15.

El-Khayat, E.F.; F.A. El-Lakwah; G.H.H. Rady; M.M.A. Ghallab and B.S. Wahba (2010). Impact of planting dates on infestation of cowpea plants with some pests. Egypt. J. Agric. Res., 88 (4): 1107-1120.

Gadi, V.P.R. and R.H. Miller (2014). Field evaluation of petroleum spray oil and carbaryl against Tetranychus marianae (Acari: Tetranychidae) on eggplant. Florida Entomological Society, 97 (1): 108-113.

Gomez, K.A. and A.A. Gomez (1984). Statistical Procedures for Agricultural Research. John Willey \& Sons, New York, $2^{\text {nd }}$ Ed.

Habashy, N.H. and F.F. Saweeres (2005). Effect of sowing dates and varieties of strawberry on the infestation with two-spotted spider mite, Tetranychus urticae Koch. Egypt. J. Agric. Res., 83 (1): 119-130.
Ibrahim, M.M.S. (2009). Effect of the host plant on susceptibility of the two-spotted spider mite, Tetranychus urticae Koch. (Acari: Tetranychidae) to some acaricides. Mansoura Univ. J. of Agric. Sci., 34 (11): 10735-10744.

Le Goff, G.; A.C. Malleux; C. Detrain; J.L. Denubourg; G. Clotuche and T. Hance (2009). Spatial distribution and inbreeding in Tetranychus urticae. Biologies, 332: 927-933.

Mohamed, M.A. (2011). Effect of planting dates on infestation with certain pests and yield parameters of squash plants. Egypt. J. Agric. Res., 89 (4): 1353-1362.

Mubammad, F.H.; M. Khalequzzaman and W. Islam (2010). Population dynamics of Tetranychus urticae Koch. and Phytoseiulus persimilis A.H. on three host plants. Pak. Entomol. Vol. 32, No. 1.

Sadek, I.I.; D.M. Mostafa and M.M. Yousry (2013). Appropriate six equations to estimate reliable growing degree-days for eggplant. American Eurasian J. Agric. \& Environ. Sci., 13 (9): 1187 1194.

Snedecor, G.W. and G.W. Cochran (1971). Statistical methods. Iowa State Univ. Press, Ames, Iowa, USA.

Solieman, T.H.; H.S. Abdel-Razzak; A.R. El-Gazzar and M.M. Doss (2012). Efficiency of mass selection and selfing with selection breeding methods on improving some important characters of three eggplant cultivars. American Eurasian J. Agric. Environ. Sci., 12 (3): 342-351.

Taha, H.A.; A.A. Shoeib; A.A. Younes and M.A. Ahmed (2001). Susceptibility of ten soybean varieties to some sucking pests with respect to certain climatic factors ineffectiveness. J. Agric. Sci. Mansoura Univ., 26 (8): 5059-5066.

\section{العلاقة بين مواعيد الزراعة وبعض العوامل الجوية علي إصابة أصناف الباذنجان بأكاروس العنكبوت الأحمر

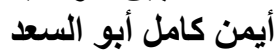 معهز بحوث وقاية النباتات ـ مركز البحوث الزراعية ـ الدقي ـ الجيزة ـ مصر}

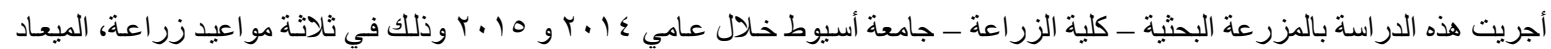

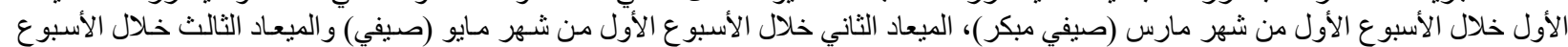

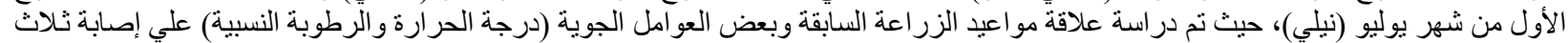

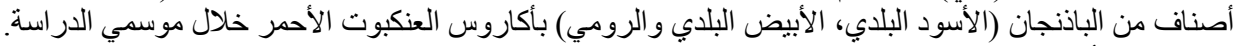

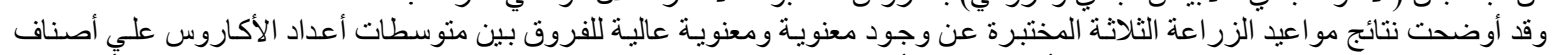

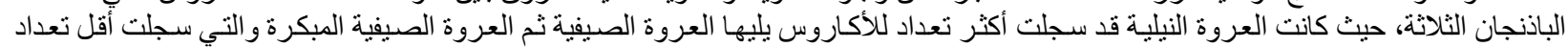

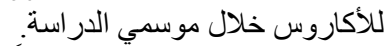

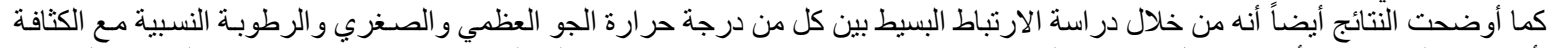

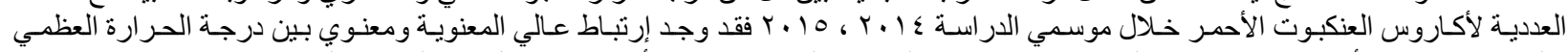

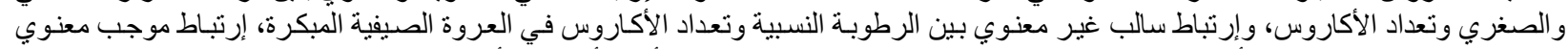

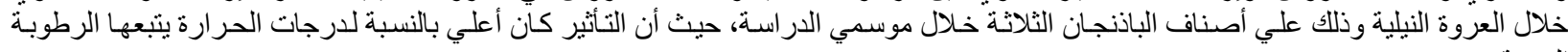

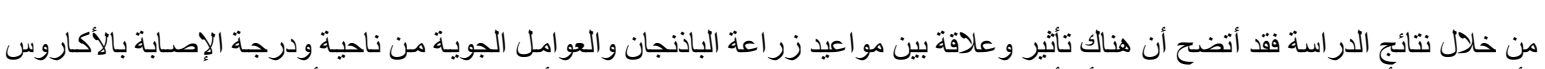

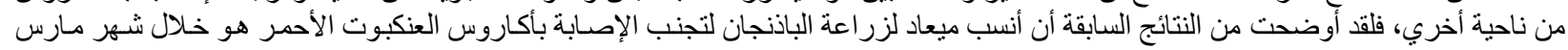

